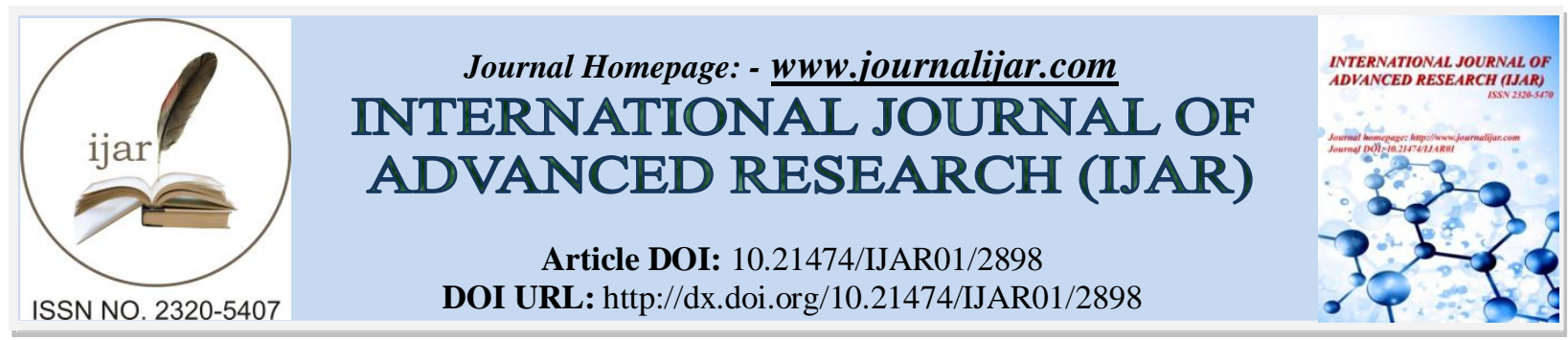

RESEARCH ARTICLE

\title{
GROSS, HISTOMORPHOLOGICAL AND HISTOCHEMICAL STUDY OF JEJUNUM IN VANARAJA AND CARI SHYAMA.
}

Payal Jain and S.P. Ingole.

Department of Veterinary Anatomy and Histology, College of Veterinary Science and A.H., Anjora, Durg (C.G.) India.

\section{Manuscript Info}

Manuscript History

Received: 23 November 2016

Final Accepted: 25 December 2016

Published: January 2017

Key words:-

Jejunum, CARI Shyama and Vanaraja

\section{Abstract}

A study was conducted on jejunum of CARI Shyama and Vanaraja crossbreds of poultry developed to improve the livelihood of peoples in the tribal area with less availability of good quality feed. Jejunum is the part of intestine plays significant role in absorption of nutrients and improves the feed utilization. Grossly, length of jejunum was significantly more in chicks and pullets of Vanaraja, however, width was more in chicks and pullets of CARI Shyama. Histologically, height of villi decreased progressively from proximal to distal segment of jejunum. Height of villi was significantly more in pullets of CARI Shyama than Vanaraja. Density of collagen fibers was more in pullets of Vanaraja than CARI Shyama. PAS activity was comparatively more in all age group of CARI Shyama than Vanaraja.

Copy Right, IJAR, 2016,. All rights reserved.

\section{Introduction:-}

CARI Shyama and Vanaraja are two hybrids introduce by the central government in the tribal area to improve the livelihood of peoples as these breeds required less classified diet than exotic breeds in Indian climate and give production better than the desi breeds. Jejunum is the part of intestine plays significant role in absorption of nutrients and improves the feed utilization. Therefore this study was undertaken to explore the status of jejunum in different age group of these birds.

\section{Material and Methods:-}

The present study was conducted on ten apparently healthy chicks ( 0 day old), growers ( 8 weeks old) and pullets (16 weeks old) of CARI Shyama and Vanaraja. Jejunum was collected, and preserved in 10\% buffered formalin. The tissue samples were processed, cut and stained with H\&E for normal histological structure, Van Gieson's for collagen fibers, Gomori's for reticular fibers, Periodic Acid Schiff (PAS) for mucopolysaccharides and AB-PAS for acid mucopolysaccharides (Singh and Sulochana, 1997).

\section{Result and Discussion:-}

The jejunum was longest and coiled part of the intestine, suspended by the mesentry and arranged in the loops at the edge of dorsal mesentry confirmed the reports of McLelland(1975), Nickel et al. (1977) and Verma (1998). Well developed yolk sac was present in the day old chick. The remnant of yolk sac in the form of Meckel's divertiulum was also noticed in growers and pullets supported the findings of King and McLelland(1975) and Nasrin et al. (2012). Number of coils of jejunum also increased with age. In pullets, number of coils ranged between 11-13, 
similar to the observation of Nickel et al. (1977).

Significantly higher length of jejunum was noticed in chicks of Vanaraja $(18.1 \mathrm{~cm})$ than CARI Shyama $(15.55 \mathrm{~cm})$, however width was significantly more in chicks of CARI Shyama than Vanaraja with an average value $0.21 \mathrm{~cm}$ and $0.15 \mathrm{~cm}$, respectively. Nasrin et al. measured $22.38 \mathrm{~cm}$ length of jejunum in day old broiler chicks and reported jejunum as longest part of the small intestine.

In growers, significantly higher width was noticed in Vanaraja with an average $0.60 \mathrm{~cm}$ than CARI Shyama $(0.56 \mathrm{~cm})$; however length was comparatively less in Vanaraja.

In pullets, pattern of length and width was similar to chicks and significant difference was noticed in the length, as length was higher in Vanaraja with mean value $74.77 \mathrm{~cm}$ than CARI Shyama $(65.4 \mathrm{~cm})$. In the present study, length and width of jejunum ranged as $65-75 \mathrm{~cm}$ and $0.50-0.60 \mathrm{~cm}$ in growers and pullets, were lesser than the findings of McLelland (1975), Nickel et al. (1977) and Verma (1998).

Table:- gross morphometrical observations of jejunum

\begin{tabular}{|c|c|c|c|c|c|c|c|c|}
\hline \multirow[t]{3}{*}{ Group } & \multirow{2}{*}{\multicolumn{2}{|c|}{$\begin{array}{l}\text { Length of Intestine } \\
\qquad(\mathrm{cm})\end{array}$}} & \multicolumn{6}{|c|}{ Jejunum } \\
\hline & & & \multicolumn{2}{|c|}{ Length $(\mathbf{c m})$} & \multicolumn{2}{|c|}{ Diameter (cm) } & \multicolumn{2}{|c|}{$\begin{array}{c}\% \text { (out of total length of } \\
\text { intestine) }\end{array}$} \\
\hline & $\begin{array}{c}\text { CARI } \\
\text { Shyama }\end{array}$ & Vanaraja & $\begin{array}{c}\text { CARI } \\
\text { Shyama }\end{array}$ & Vanaraja & $\begin{array}{c}\text { CARI } \\
\text { Shyama }\end{array}$ & Vanaraja & $\begin{array}{l}\text { CARI } \\
\text { Shyama }\end{array}$ & Vanaraja \\
\hline Chicks & $\begin{array}{c}27.5 \pm \\
1.02\end{array}$ & $\begin{array}{l}31.4 \pm \\
0.79^{*}\end{array}$ & $\begin{array}{c}15.55 \pm \\
0.67\end{array}$ & $\begin{array}{l}18.1 \pm \\
0.51^{*}\end{array}$ & $\begin{array}{l}0.21 \pm \\
0.006^{*}\end{array}$ & $\begin{array}{l}0.15 \pm \\
0.004\end{array}$ & $\begin{array}{c}56.71 \pm \\
1.87 \\
\end{array}$ & $\begin{array}{c}57.70 \pm \\
1.12\end{array}$ \\
\hline Growers & $\begin{array}{c}113.3 \pm \\
1.4\end{array}$ & $119 \pm 2.62$ & $\begin{array}{l}73.5 \pm \\
0.74\end{array}$ & $\begin{array}{l}71.83 \pm \\
2.57\end{array}$ & $\begin{array}{l}0.56 \pm \\
0.014\end{array}$ & $\begin{array}{l}0.60 \pm \\
0.014^{*}\end{array}$ & $\begin{array}{l}64.91 \pm \\
0.50\end{array}$ & $\begin{array}{l}60.35 \pm \\
1.85\end{array}$ \\
\hline Pullets & $\begin{array}{c}108.4 \pm \\
2.41 \\
\end{array}$ & $\begin{array}{c}122.1 \pm \\
1.40^{*}\end{array}$ & $\begin{array}{l}65.4 \pm \\
2.14\end{array}$ & $\begin{array}{l}74.77 \pm \\
2.02^{*}\end{array}$ & $\begin{array}{c}0.57 \pm \\
0.013 \\
\end{array}$ & $\begin{array}{l}0.59 \pm \\
0.012 \\
\end{array}$ & $\begin{array}{c}60.38 \pm \\
1.62\end{array}$ & $\begin{array}{l}61.20 \pm \\
1.40\end{array}$ \\
\hline
\end{tabular}

Table:- Histomorphometrical Observations Of Jejunum.

\begin{tabular}{|c|c|c|c|c|c|c|c|c|c|c|c|c|c|c|c|c|c|}
\hline \multirow[t]{3}{*}{$\begin{array}{c}\text { Grou } \\
\mathrm{p}\end{array}$} & \multirow[t]{3}{*}{ Breed } & \multirow{2}{*}{\multicolumn{2}{|c|}{$\begin{array}{l}\text { Thickness } \\
\text { of wall }^{\mathrm{a}} \\
(\mu \mathrm{m})\end{array}$}} & \multirow{2}{*}{\multicolumn{2}{|c|}{$\begin{array}{c}\text { Thickness } \\
\text { of tunica } \\
\text { muscular } \\
(\mu \mathrm{m})\end{array}$}} & \multirow{2}{*}{\multicolumn{2}{|c|}{$\begin{array}{c}\text { Thickness } \\
\text { of propria } \\
\text { submucos } \\
a^{b} \\
(\mu \mathrm{m})\end{array}$}} & \multicolumn{4}{|c|}{$\begin{array}{l}\text { Diameter of gland } \\
\qquad(\mu \mathrm{m})\end{array}$} & \multicolumn{6}{|c|}{$\begin{array}{l}\text { Height of epithelium of villi/ } \\
\text { folds } \\
(\mu \mathrm{m})\end{array}$} \\
\hline & & & & & & & & \multicolumn{2}{|c|}{$\begin{array}{c}\text { Maximu } \\
\mathrm{m}\end{array}$} & \multicolumn{2}{|c|}{ minimum } & \multicolumn{2}{|c|}{ Base } & \multicolumn{2}{|c|}{ middle } & \multicolumn{2}{|c|}{ Apex } \\
\hline & & $\begin{array}{c}\text { Mea } \\
n\end{array}$ & SE & $\begin{array}{c}\text { Mea } \\
\text { n }\end{array}$ & SE & $\begin{array}{c}\text { Mea } \\
\mathrm{n}\end{array}$ & SE & $\begin{array}{l}\mathrm{Me} \\
\text { an }\end{array}$ & SE & $\begin{array}{l}\text { Me } \\
\text { an }\end{array}$ & SE & $\begin{array}{c}\mathrm{Me} \\
\text { an }\end{array}$ & SE & $\begin{array}{l}\mathrm{Me} \\
\text { an }\end{array}$ & SE & $\begin{array}{l}\mathrm{Me} \\
\text { an }\end{array}$ & SE \\
\hline \multirow[t]{2}{*}{$\begin{array}{c}\text { Chic } \\
\text { ks }\end{array}$} & $\begin{array}{c}\text { CARI } \\
\text { Shya } \\
\text { ma }\end{array}$ & $\begin{array}{c}123 . \\
44\end{array}$ & $\begin{array}{l}4 . \\
16\end{array}$ & 60.8 & $\begin{array}{c}3.5 \\
2\end{array}$ & $\begin{array}{c}47.3 \\
8\end{array}$ & $\begin{array}{c}3.0 \\
4\end{array}$ & $\begin{array}{l}18 . \\
72\end{array}$ & $\begin{array}{l}2 . \\
92\end{array}$ & 14 & $\begin{array}{l}2 . \\
36\end{array}$ & $\begin{array}{c}13 . \\
2\end{array}$ & $\begin{array}{c}0 . \\
72\end{array}$ & $\begin{array}{l}13 . \\
04\end{array}$ & $\begin{array}{l}0 . \\
68\end{array}$ & $\begin{array}{l}11 . \\
44\end{array}$ & $\begin{array}{l}1 . \\
08\end{array}$ \\
\hline & $\begin{array}{l}\text { Vana } \\
\text { raja }\end{array}$ & $\begin{array}{c}133 . \\
28\end{array}$ & $\begin{array}{c}4 . \\
32\end{array}$ & $\begin{array}{c}62.7 \\
2\end{array}$ & $\begin{array}{c}2.2 \\
4\end{array}$ & $\begin{array}{c}50.7 \\
2\end{array}$ & $\begin{array}{c}2.0 \\
8\end{array}$ & $\begin{array}{l}24 . \\
36\end{array}$ & $\begin{array}{l}2 . \\
96\end{array}$ & $\begin{array}{l}15 . \\
48\end{array}$ & $\begin{array}{c}2 . \\
04\end{array}$ & $\begin{array}{l}14 . \\
08\end{array}$ & $\begin{array}{c}0 . \\
84\end{array}$ & $\begin{array}{l}14 . \\
32\end{array}$ & $\begin{array}{c}0 . \\
72\end{array}$ & $\begin{array}{l}11 . \\
88\end{array}$ & $\begin{array}{c}1 . \\
24\end{array}$ \\
\hline \multirow[t]{2}{*}{$\begin{array}{l}\text { Grow } \\
\text { ers }\end{array}$} & $\begin{array}{c}\text { CARI } \\
\text { Shya } \\
\text { ma }\end{array}$ & $\begin{array}{c}293 . \\
28\end{array}$ & $\begin{array}{c}20 \\
.8\end{array}$ & $\begin{array}{c}139 . \\
2\end{array}$ & $\begin{array}{l}10 . \\
56\end{array}$ & $\begin{array}{c}123 . \\
36\end{array}$ & $\begin{array}{l}12 . \\
96\end{array}$ & $\begin{array}{c}81 . \\
6\end{array}$ & $\begin{array}{l}3 . \\
36\end{array}$ & $\begin{array}{c}50 . \\
4\end{array}$ & $\begin{array}{l}1 . \\
44\end{array}$ & $\begin{array}{c}38 . \\
4\end{array}$ & $\begin{array}{l}1 . \\
92\end{array}$ & $\begin{array}{l}34 . \\
88\end{array}$ & $\begin{array}{l}2 . \\
56\end{array}$ & $\begin{array}{l}29 . \\
12\end{array}$ & $\begin{array}{l}3 . \\
2\end{array}$ \\
\hline & $\begin{array}{l}\text { Vana } \\
\text { raja }\end{array}$ & $\begin{array}{c}319 . \\
04 .\end{array}$ & $\begin{array}{l}17 \\
.6\end{array}$ & $\begin{array}{c}183 . \\
68^{*}\end{array}$ & $\begin{array}{c}11 . \\
2\end{array}$ & 128 & $\begin{array}{c}8.9 \\
6\end{array}$ & $\begin{array}{c}90 . \\
56\end{array}$ & $\begin{array}{c}5 . \\
52\end{array}$ & $\begin{array}{c}52 . \\
8\end{array}$ & $\begin{array}{c}1 . \\
92\end{array}$ & $\begin{array}{c}41 . \\
6\end{array}$ & $\begin{array}{c}1 . \\
76\end{array}$ & $\begin{array}{l}36 . \\
16\end{array}$ & $\begin{array}{r}2 . \\
72\end{array}$ & $\begin{array}{l}25 . \\
28\end{array}$ & $\begin{array}{l}1 . \\
44\end{array}$ \\
\hline \multirow[t]{2}{*}{$\begin{array}{c}\text { Pulle } \\
\text { ts }\end{array}$} & $\begin{array}{c}\text { CARI } \\
\text { Shya } \\
\text { ma }\end{array}$ & $\begin{array}{c}404 . \\
4^{*}\end{array}$ & $\begin{array}{r}20 \\
.8\end{array}$ & $188^{*}$ & $\begin{array}{l}12 . \\
16\end{array}$ & 152 & $\begin{array}{l}10 . \\
24\end{array}$ & $83^{*}$ & $\begin{array}{l}1 . \\
34\end{array}$ & $\begin{array}{l}60 . \\
64^{*}\end{array}$ & $\begin{array}{l}1 . \\
6\end{array}$ & $\begin{array}{c}66 . \\
4\end{array}$ & $\begin{array}{l}4 . \\
32\end{array}$ & $\begin{array}{l}68 . \\
16\end{array}$ & 4 & 52 & $\begin{array}{l}3 . \\
68\end{array}$ \\
\hline & $\begin{array}{c}\text { Vana } \\
\text { raja }\end{array}$ & $\begin{array}{c}287 . \\
68\end{array}$ & $\begin{array}{r}26 \\
.4 \\
\end{array}$ & $\begin{array}{c}126 . \\
72\end{array}$ & $\begin{array}{l}14 . \\
24\end{array}$ & $\begin{array}{c}115 . \\
36\end{array}$ & $\begin{array}{l}14 . \\
56 \\
\end{array}$ & $\begin{array}{c}70 . \\
4 \\
\end{array}$ & 4 & $\begin{array}{l}52 . \\
16 \\
\end{array}$ & $\begin{array}{c}1 . \\
76\end{array}$ & $\begin{array}{l}65 . \\
92\end{array}$ & $\begin{array}{c}1 . \\
92\end{array}$ & $\begin{array}{l}67 . \\
04\end{array}$ & $\begin{array}{l}3 . \\
68\end{array}$ & $\begin{array}{r}56 . \\
16 \\
\end{array}$ & $\begin{array}{l}2 . \\
88\end{array}$ \\
\hline
\end{tabular}

Thickness of wall from base of the villi to tunica serosa, b. Thickness of propria submucosa from base of the villi, observations could not be

taken. Mean values with * are significant $(\mathbf{P}<\mathbf{0 . 0 5})$ 
Table:- Histomorphometrical Observations Of Jejunum.

\begin{tabular}{|c|c|c|c|c|c|c|c|c|c|c|c|c|c|c|c|c|c|}
\hline \multirow{3}{*}{$\begin{array}{c}\text { Grou } \\
\mathrm{p}\end{array}$} & \multirow{3}{*}{$\begin{array}{c}\text { Bree } \\
\text { d }\end{array}$} & \multirow{2}{*}{\multicolumn{2}{|c|}{$\begin{array}{l}\text { Average } \\
\text { height of } \\
\text { villi/ folds } \\
(\mu \mathrm{m})\end{array}$}} & \multicolumn{6}{|c|}{ Height of villi/ folds $(\mu \mathrm{m})$} & \multicolumn{6}{|c|}{ Width of villi/ folds $(\mu \mathrm{m})$} & \multirow{2}{*}{\multicolumn{2}{|c|}{$\begin{array}{c}\text { No. of } \\
\text { villi/ } \\
\text { folds }\end{array}$}} \\
\hline & & & & \multicolumn{2}{|c|}{$\begin{array}{c}\begin{array}{c}\text { Long } \\
\text { (above }\end{array} \\
1000 \mu \mathrm{m})\end{array}$} & \multicolumn{2}{|c|}{$\begin{array}{c}\text { Medium } \\
(500-1000 \\
\mu \mathrm{m})\end{array}$} & \multicolumn{2}{|c|}{$\begin{array}{l}\text { Small } \\
(0-500 \\
\mu \mathrm{m})\end{array}$} & \multicolumn{2}{|c|}{ Base } & \multicolumn{2}{|c|}{ Middle } & \multicolumn{2}{|c|}{ Apex } & & \\
\hline & & $\begin{array}{c}\mathrm{Me} \\
\text { an }\end{array}$ & SE & $\begin{array}{c}\text { Mea } \\
\mathrm{n}\end{array}$ & $\mathrm{SE}$ & $\begin{array}{c}\mathrm{Me} \\
\text { an }\end{array}$ & $\mathrm{SE}$ & $\begin{array}{c}\text { Mea } \\
\mathrm{n}\end{array}$ & $\mathrm{SE}$ & $\begin{array}{c}\text { Mea } \\
\mathrm{n}\end{array}$ & SE & $\begin{array}{c}\mathrm{Me} \\
\text { an }\end{array}$ & SE & $\begin{array}{c}\mathrm{Me} \\
\text { an }\end{array}$ & $\begin{array}{l}S \\
E\end{array}$ & $\begin{array}{c}\mathrm{Me} \\
\text { an }\end{array}$ & $\begin{array}{l}S \\
E\end{array}$ \\
\hline \multirow[t]{2}{*}{$\begin{array}{c}\text { Chic } \\
\text { ks }\end{array}$} & $\begin{array}{c}\text { CAR } \\
\text { I } \\
\text { Shya } \\
\text { ma }\end{array}$ & $\begin{array}{c}198 \\
.4\end{array}$ & $\begin{array}{c}22 . \\
4\end{array}$ & & & & & & & $\begin{array}{c}65.2 \\
8\end{array}$ & $\begin{array}{c}3.6 \\
8\end{array}$ & $\begin{array}{l}63 . \\
68\end{array}$ & 3.2 & $\begin{array}{c}51 . \\
2\end{array}$ & $\begin{array}{c}2 . \\
4\end{array}$ & $\begin{array}{c}28 . \\
8\end{array}$ & $\begin{array}{c}1 . \\
05\end{array}$ \\
\hline & $\begin{array}{c}\text { Vana } \\
\text { raja }\end{array}$ & 164 & $\begin{array}{l}12 . \\
16\end{array}$ & & & & & & & $\begin{array}{c}60.3 \\
2\end{array}$ & $\begin{array}{c}2.0 \\
8\end{array}$ & $\begin{array}{l}61 . \\
76\end{array}$ & $\begin{array}{c}2.0 \\
8\end{array}$ & $\begin{array}{l}51 . \\
52\end{array}$ & $\begin{array}{l}2 . \\
24\end{array}$ & $\begin{array}{c}28 . \\
8\end{array}$ & $\begin{array}{l}1 . \\
6\end{array}$ \\
\hline \multirow[t]{2}{*}{$\begin{array}{c}\text { Gro } \\
\text { wers }\end{array}$} & $\begin{array}{c}\text { CAR } \\
\text { I } \\
\text { Shya } \\
\text { ma } \\
\end{array}$ & $\begin{array}{r}759 \\
.28\end{array}$ & $\begin{array}{l}79 . \\
52\end{array}$ & $\begin{array}{c}1086 \\
.88\end{array}$ & 9.6 & $\begin{array}{c}813 \\
.4\end{array}$ & $\begin{array}{c}35 . \\
2\end{array}$ & $\begin{array}{c}355 . \\
52\end{array}$ & $\begin{array}{c}9.9 \\
2\end{array}$ & $\begin{array}{l}198 . \\
24^{*}\end{array}$ & $\begin{array}{c}4.4 \\
8\end{array}$ & $\begin{array}{c}126 \\
.72\end{array}$ & 8 & $\begin{array}{l}94 . \\
72\end{array}$ & $\begin{array}{c}8 . \\
32\end{array}$ & $\begin{array}{c}45 . \\
4\end{array}$ & $\begin{array}{l}2 . \\
44\end{array}$ \\
\hline & $\begin{array}{c}\text { Vana } \\
\text { raja }\end{array}$ & $\begin{array}{c}682 \\
.4 \\
\end{array}$ & $\begin{array}{l}53 . \\
44 \\
\end{array}$ & $\begin{array}{c}1044 \\
.48\end{array}$ & $\begin{array}{c}6.5 \\
6 \\
\end{array}$ & $\begin{array}{r}745 \\
.82 \\
\end{array}$ & $\begin{array}{c}41 . \\
6\end{array}$ & $\begin{array}{c}346 . \\
88 \\
\end{array}$ & $\begin{array}{l}15 . \\
68\end{array}$ & 168 & $\begin{array}{l}11 . \\
52\end{array}$ & $\begin{array}{r}122 \\
.48 \\
\end{array}$ & $\begin{array}{l}10 . \\
24\end{array}$ & $\begin{array}{c}83 . \\
2\end{array}$ & $\begin{array}{l}3 . \\
84\end{array}$ & $\begin{array}{c}45 . \\
1 \\
\end{array}$ & $\begin{array}{r}2 . \\
33\end{array}$ \\
\hline \multirow[t]{2}{*}{$\begin{array}{l}\text { Pulle } \\
\text { ts }\end{array}$} & $\begin{array}{c}\text { CAR } \\
\text { I } \\
\text { Shya } \\
\text { ma } \\
\end{array}$ & $\begin{array}{l}922 \\
.4^{*}\end{array}$ & $\begin{array}{c}75 . \\
2\end{array}$ & $\begin{array}{c}1215 \\
.36\end{array}$ & $\begin{array}{l}16 . \\
64\end{array}$ & $\begin{array}{l}779 \\
.68\end{array}$ & $\begin{array}{l}26 . \\
56\end{array}$ & $\begin{array}{c}412 . \\
16^{*}\end{array}$ & $\begin{array}{l}10 . \\
24\end{array}$ & $\begin{array}{c}136 . \\
8\end{array}$ & $\begin{array}{c}6.5 \\
6\end{array}$ & $\begin{array}{r}121 \\
.92\end{array}$ & $\begin{array}{c}6.7 \\
2\end{array}$ & $\begin{array}{r}119 \\
.04\end{array}$ & $\begin{array}{l}7 . \\
68\end{array}$ & $\begin{array}{c}42 . \\
3\end{array}$ & $\begin{array}{l}2 . \\
87\end{array}$ \\
\hline & $\begin{array}{c}\text { Vana } \\
\text { raja }\end{array}$ & $\begin{array}{c}635 \\
.2 \\
\end{array}$ & $\begin{array}{l}69 . \\
92\end{array}$ & $\begin{array}{c}1220 \\
. .48\end{array}$ & $\begin{array}{c}21 . \\
6\end{array}$ & $\begin{array}{r}709 \\
.12 \\
\end{array}$ & $\begin{array}{l}31 . \\
04\end{array}$ & $\begin{array}{c}346 . \\
4\end{array}$ & $\begin{array}{c}7.8 \\
4 \\
\end{array}$ & $\begin{array}{c}123 . \\
36\end{array}$ & $\begin{array}{l}13 . \\
12\end{array}$ & $\begin{array}{c}105 \\
.6\end{array}$ & $\begin{array}{c}7.6 \\
8 \\
\end{array}$ & $\begin{array}{c}100 \\
.8\end{array}$ & $\begin{array}{c}6 . \\
24\end{array}$ & $\begin{array}{c}42 . \\
8\end{array}$ & $\begin{array}{l}2 . \\
24\end{array}$ \\
\hline
\end{tabular}

Blank- Villi of these categories were not present

Mean values with * are significant $(\mathbf{P}<0.05)$

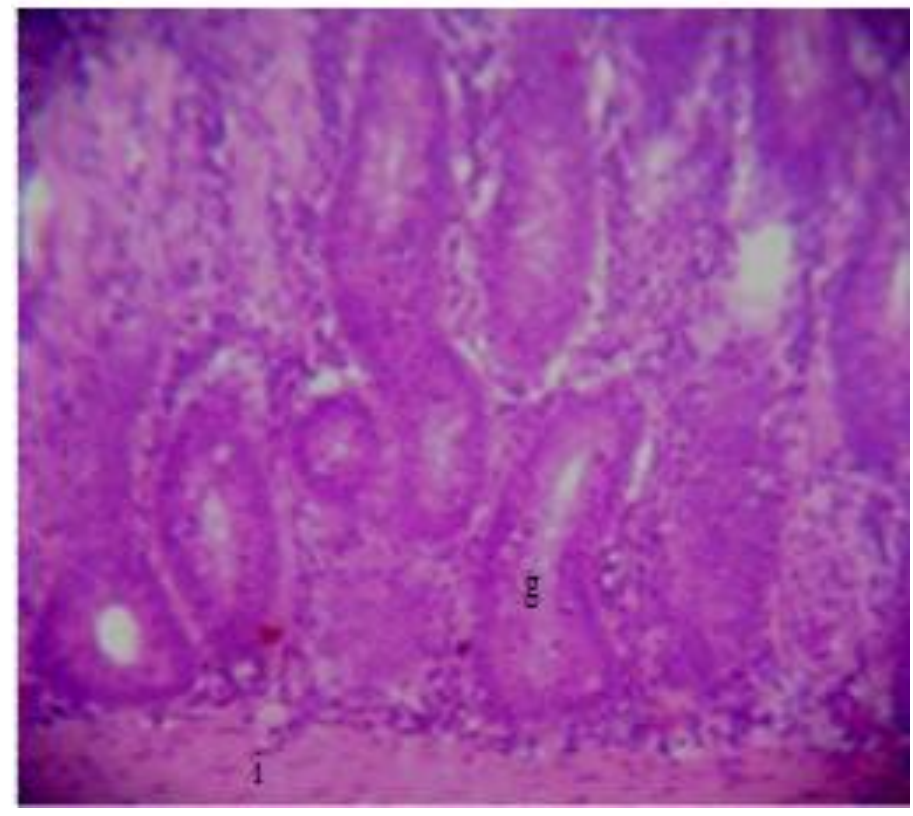

Fig.1:- Photomicrograph of jejunum of CARI Shyama (group 3) showing glandular unit (g) and tunica muscularis (i) $(\mathrm{H} \& \mathrm{E}, 400 \mathrm{X})$. 


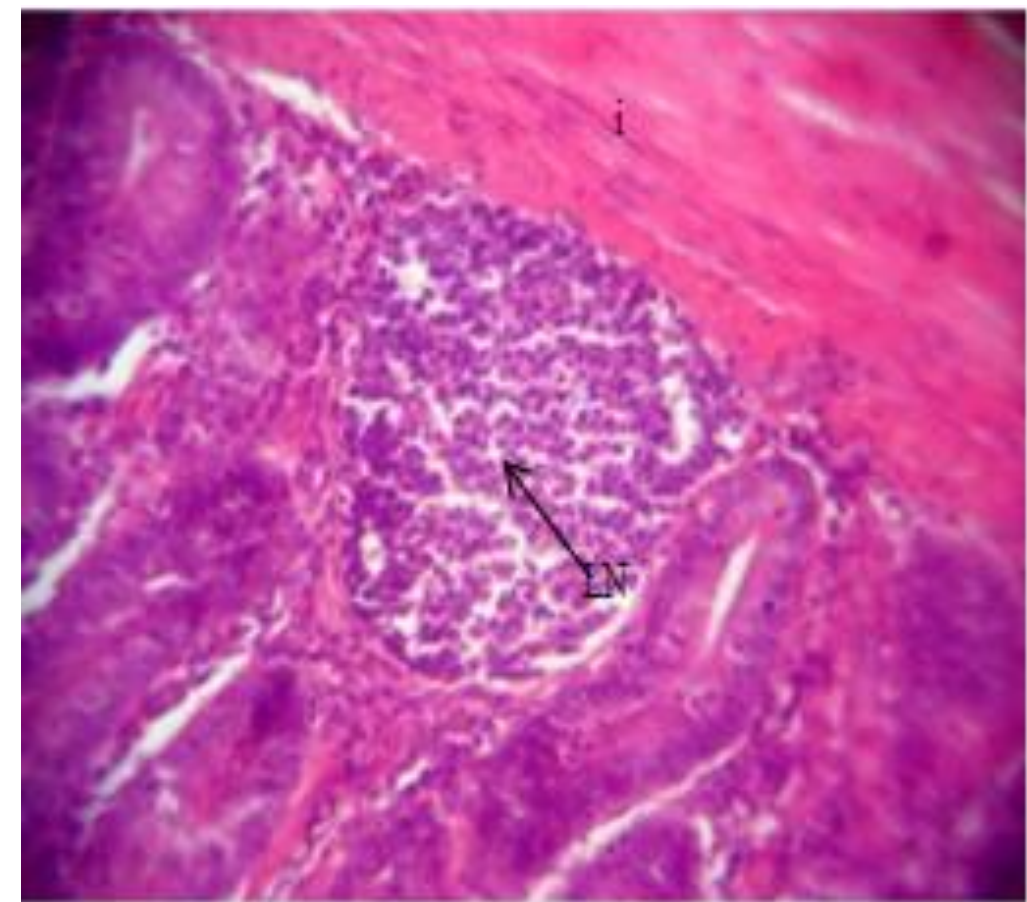

Fig. 2:- Photomicrograph of jejunum of Vannaraja (group 2) showing lymphatic nodule (LN) and tunica muscularis (i) (H\&E, 400X)

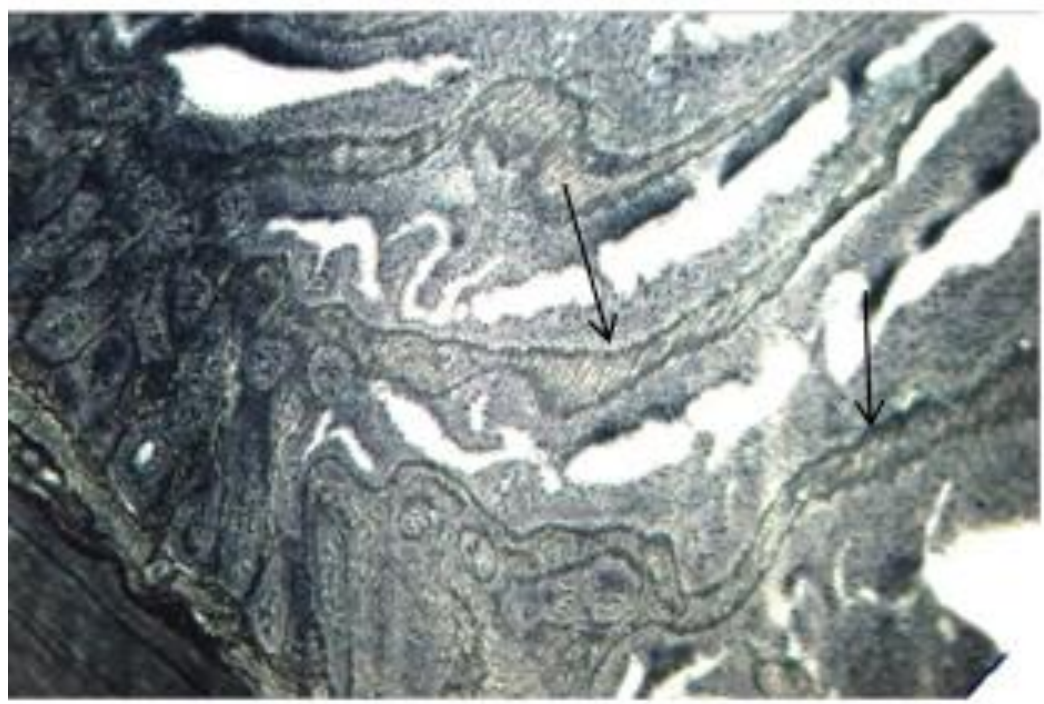

Fig.3:- Photomicrograph of jejunum of Vanaraja (group 3) showing reticular fibers (arrow) in the core of villi (Gomori's, 100X) 


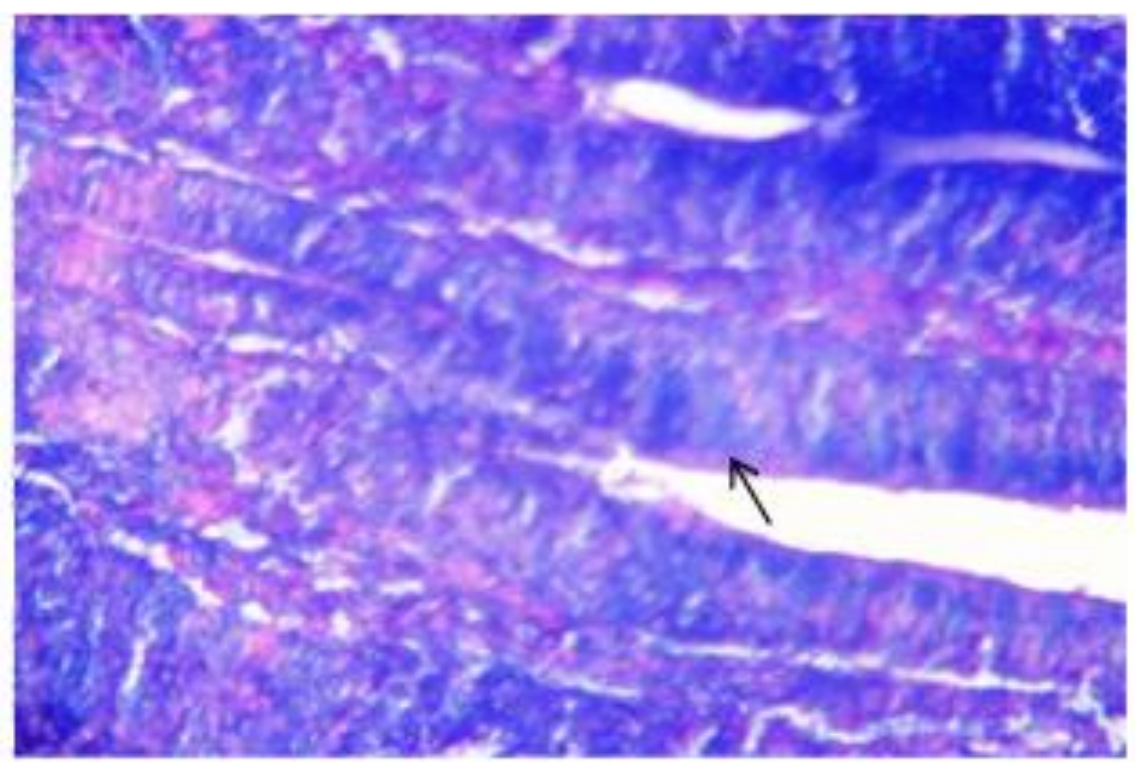

Fig.4:- Photomicrograph of jejunum of CARI Shyama (group 2) showing AB-PAS activity (arrow) in mucosal epithelium (AB-PAS, 400X)

In chicks, more uniformity was observed in height and shape of villi in proximal part of jejunum than the distal part. Number of goblet cells was comparatively more in pullets of Vanaraja than CARI Shyama. Height of villi decreased progressively than the earlier segment; it is in accordance to the findings of Hodges (1974), McLelland (1975) and Verma et al. (1998). In chicks, villi were tongue or leaf shaped. The average height of villi was significantly more in pullets of CARI Shyama with mean value $922.4 \mu \mathrm{m}$ than Vanaraja $(635.2 \mu \mathrm{m})$. Height of villi in pullets of CARI Shyama exceeded than in the duodenum and might be indicative of more active jejunum. Height of villi ranged between $150-200 \mu \mathrm{m}$ in chicks, $300-1100 \mu \mathrm{m}$ in growers and 300-1250 $\mu \mathrm{m}$ in pullets. In growers, width of villi increased at all level in CARI Shyama, however in Vanaraja, width only increased at middle of villi. Observation in present study are in accordance to the reports of Hodges (1974), McLelland (1975), Verma et al. (1998) and Nasrin et al.(2012), that broad villi were observed in the jejunum. Significant difference in width was noticed only at base of villi in growers of CARI Shyama with mean value $198.24 \mu \mathrm{m}$ than Vanaraja $(168 \mu \mathrm{m})$. Height of small sized villi was significantly less in pullets of Vanaraja $(346.4 \mu \mathrm{m})$ than CARI Shyama $(412.16 \mu \mathrm{m})$. In growers and pullets, distance between adjacent villi increased, which might be due to decrease in total number of villi. Cellularity of lamina propria decreased than earlier segment due to less infiltration of lymphocytes.

The glandular units in lamina propria were more in pullets of CARI Shyama than Vanaraja, however overall number of glandular units decreased than the earlier segment in all age groups (fig.1). Tubular glands were significantly larger in pullets of CARI Shyama than Vanaraja.

Lymphocytes infiltration was more marked in the pullets of CARI Shyama than Vanaraja. Less lymphocytic infiltration than the earlier region of intestine supported the finding of Bradley and Grahame (1960) and was not in agreement to McLelland (1975) who reported increased lymphatic infiltration in jejunum. Lymphatic nodule formation was noticed in the proximal segment of jejunum of growers and pullets(fig.2), however nodules were absent in chicks.

Significant differences were noticed in the thickness of tunica muscularis of growers of Vanaraja than CARI Shyama with the mean value $183.68 \mu \mathrm{m}$ and $139.2 \mu \mathrm{m}$, respectively. In growers of Vanaraja, thickness of tunica muscularis was comparatively more than the duodenum, which is in agreement to the finding of Vaish (2005), however in other birds such pattern was not found. In pullets, total thickness of wall and tunica muscularis was significantly more in CARI Shyama with mean value $404.4 \mu \mathrm{m}$ and $188 \mu \mathrm{m}$ than $287.68 \mu \mathrm{m}$ and $126.72 \mu \mathrm{m}$ in Vanaraja, respectively.

Localization of collagen, elastic and reticular fibers was established in the core of the villi, inter glandular connective tissue, lamina muscularis, submucosa, inter muscular connective tissue and in subserosal connective 
tissue. The density of the collagen fibers in the intestinal wall was more in comparison to elastic and reticular fibers which confirmed the findings of Verma et al. (1999) and Vaish (2005). In initial segment of jejunum, density of collagen fibers was more in chicks and growers of CARI Shyama, while in distal segment density was more in chicks and growers of Vanaraja.

Density of reticular fibers was more in chicks of CARI Shyama and growers of Vanaraja, while in pullets, density was more in Vanaraja (fig.3). Peculiar arrangement of fibers was seen in the jejunum as peripheral thick fibers were joined by thin fibers net in the core of villi. Crossing strands of reticular fibers in the circular muscle bundles were also noticed.

PAS positive material was noticed in the mucosal and glandular epithelium and in smooth muscles of lamina propria and tunica muscularis. In jejunum, activity was comparatively more in all age groups of CARI Shyama than Vanaraja. PAS activity was mild in chicks and growers of Vanaraja and mild to moderate in pullets; however activity was moderate to intense in chicks and pullets of CARI Shyama and moderate in growers. More activity was recorded in distal region of jejunum in chicks of CARI Shyama, which might be indicative of early maturity of these regions in the respective breed to digest the complex carbohydrate.

Droplet like AB-PAS positive material was noticed in the apical part of epithelium of villi and glandular units in chicks and pullet. Diffuse activity was noticed in growers (fig.4). In Jejunum, more activity was noticed in the initial two third segments, in chicks and pullets of Vanaraja and growers of CARI Shyama. However, in distal segment, activity was more pronounced in chicks and pullets of CARI Shyama and growers of Vanaraja.

\section{Refrences:-}

1. Bradley, O.C. and Grahame, T. 1960. The Structure of the Fowl. $4^{\text {th }}$ ed. Oliver and Boyd, Edinburgh, London. pp. 31-50.

2. Hodges, R.D. 1974. The Histology of the Fowl. Academic Press, London. pp. 35-112.

3. King, A.S. and McLelland, J. 1975. Outlines of Avian Anatomy. ${ }^{\text {st }}$ ed. Bailliere Tindall, London. pp. 33-42.

4. McLelland. J. 1975. Aves digestive system. In: Getty, R. (ed). Sisson and Grossman's The Anatomy of the Domestic Animals. Vol. 2. $5^{\text {th }}$ ed. W.B. Saunders Company, Philadelphia. pp. 1857-1882.

5. Nasrin, M., Siddiqi, M.N.H., Masum, M.A. and Wares, M.A. 2012. Gross and histological studies of digestive tract of broilers during postnatal growth and development. J.Bangladesh Agril.Univ. 10(1) :69-77.

6. Nickel, R., Schummer, A. and Seiferle, E. 1977. Anatomy of the Domestic Birds (Translated by W. J. Siller and P.A. L. Wright), Verlag Paul Parey, Berlin pp. 75-81.

7. Singh, U.B. and Sulochana, S. 1997. Handbook of Histological Technique. Premier Publishing House, Kothi, Hyderabad. pp. 42-63.

8. Vaish, M.K. 2005. Pre and post hatch developmental studies on digestive system of Kadaknath fowl. M.V.Sc. Thesis, Jawaharlal Nehru Krishi Vishwavidalaya, Jabalpur. pp. 25-58.

9. Verma, D. 1998. Pre and posthatch morphogenesis of digestive system in fowl (Gallus domesticus). M.V.Sc. Thesis, Jawaharlal Nehru Krishi Vishwavidalaya, Jabalpur. pp. 24-57.

10. Verma, D., Malik, M.R., Parmar, M.L. and Shrivastava, A.M. 1999. Histochemical studies of intestine in pre and post hatch fowl (Gallus domesticus). Indian J. Vet. Anat. 11(1) : 11-14.

11. Verma, D., Malik, M.R., Parmar, M.L. and Taluja, J.S. 1998. Histogenesis of intestine in pre and posthatch chicken. Indian J. Vet. Anat. 10 (1/2): 76-85. 